University of Nebraska - Lincoln

DigitalCommons@University of Nebraska - Lincoln

\title{
Comparative water quality and channel catfish production in earthen ponds and a biofloc technology production system
}

Bartholomew W. Green

bart.green@usda.gov

Matthew E. McEntire

USDA, Agricultural Research Service

Follow this and additional works at: https://digitalcommons.unl.edu/usdaarsfacpub

Part of the Agriculture Commons, and the Aquaculture and Fisheries Commons

Green, Bartholomew W. and McEntire, Matthew E., "Comparative water quality and channel catfish production in earthen ponds and a biofloc technology production system" (2017). Publications from USDA-ARS / UNL Faculty. 2424.

https://digitalcommons.unl.edu/usdaarsfacpub/2424

This Article is brought to you for free and open access by the U.S. Department of Agriculture: Agricultural Research Service, Lincoln, Nebraska at DigitalCommons@University of Nebraska - Lincoln. It has been accepted for inclusion in Publications from USDA-ARS / UNL Faculty by an authorized administrator of DigitalCommons@University of Nebraska - Lincoln. 


\title{
Comparative water quality and channel catfish production in earthen ponds and a biofloc technology production system
}

\author{
Bartholomew W. Green and Matthew E. McEntire \\ U.S. Department of Agriculture, Agriculture Research Service, Harry K. Dupree Stuttgart National \\ Aquaculture Research Center, Stuttgart, Arkansas, USA
}

\begin{abstract}
This 210-day study compared variation in water quality and fish growth for channel catfish (Ictalurus punctatus; $47 \mathrm{~g} /$ fish) stocked in earthen ponds (1.5 fish $/ \mathrm{m}^{2}, 14,820 / \mathrm{ha}$ ) and in a biofloc technology (BFT) production system with high-density polyethylene-lined rectangular tanks (12.6 fish/m $\left.\mathrm{m}^{2}, 126,000 / \mathrm{ha}\right)$. Feed input and culture environment affected water-quality dynamics. In ponds, phytoplankton uptake predominated and little nitrification occurred, whereas in the BFT system phytoplankton uptake and nitrification maintained low ammonia-nitrogen concentrations. Size classes of fish were skewed toward the larger market sizes in ponds and toward smaller market sizes in the BFT system. Mean final fish weight was $630 \mathrm{~g} / \mathrm{fish}$ in ponds and $542 \mathrm{~g} /$ fish in the BFT system. Despite these differences, fish yield was higher in the BFT system $\left(7.7 \mathrm{~kg} / \mathrm{m}^{3} \mathrm{v} .1 .5 \mathrm{~kg} / \mathrm{m}^{3}\right)$ because of the greater initial stocking rate.
\end{abstract}

\section{KEYWORDS}

Biofloc technology; channel catfish; earthen ponds; Ictalurus punctatus; market-size fish; water quality

\section{Introduction}

Pond management strategies to produce food-size catfish are varied and have evolved over time toward increased intensification (Johnson et al. 2014). Pond catfish culture is intensified further using the split-pond system (Brown et al. 2016; Park et al. 2014), which evolved from the partitioned aquaculture system (Brune et al. 2004). In split-pond catfish culture, a traditional earthen pond is divided into two sections: a fish-production section (ca. 10\%-20\% of original pond area) and a waste-treatment section. Water is circulated continuously between the two sections during the day, but circulation ceases at night. Photosynthesis supplies dissolved oxygen during the day, and flow rate between the two sections of the split pond is adjusted to ensure the minimum required oxygen concentration for fish growth (Brown et al. 2016). Paddlewheel aeration is used in the fish-production section at night.

CONTACT Bartholomew W. Green Bart.Green@ars.usda.gov E U.S. Department of Agriculture, Agricultural Research Service, Harry K. Dupree Stuttgart National Aquaculture Research Center, 2955 Highway 130 East, P.O. Box 1050, Stuttgart, AR 72160, USA.

This article not subject to U.S. copyright law. 
The biofloc technology (BFT) production system could represent a further intensification of catfish culture. High yields of fish or shrimp are produced in the BFT system because two important production-limiting factors, dissolved oxygen and total ammonia-nitrogen (TAN) concentrations, are maintained at near-optimal levels despite high stocking and feeding rates (Hargreaves 2006). In an outdoor BFT production system, a complex of living organisms is closely associated with particulate organic matter and is maintained in suspension by continuous aeration. TAN excreted by the culture animal is utilized by the phytoplankton and bacteria that are part of this complex of living organisms. Channel catfish have been grown successfully in an outdoor experimental BFT production system (Green 2010; Green et al. 2014), which differs substantially from traditional earthen pond grow-out. In traditional earthen pond culture, mechanical aeration is used at night to maintain dissolved oxygen concentration above critical levels, and algal photosynthesis is the primary source of dissolved oxygen and the principal sink for excreted TAN. The objective of this study was thus to evaluate variation in water quality and fish growth for channel catfish stocked in earthen ponds or the BFT production system.

\section{Materials and methods}

Three 0.04-ha earthen ponds $\left(228 \mathrm{~m}^{3}\right)$ and three outdoor, rectangular woodframed, high-density polyethylene-lined tanks $\left(18.6 \mathrm{~m}^{2}, 15.7 \mathrm{~m}^{3}\right)$ located at the Harry K. Dupree Stuttgart National Aquaculture Research Center (HKDSNARC), Stuttgart, Arkansas, were used for this study. Each earthen pond was equipped with an electric paddlewheel aerator $(13.8 \mathrm{~kW} / \mathrm{ha}, 208 \mathrm{~V}$, 3 -phase) that was activated by data logger to maintain minimum dissolved oxygen concentration above $40 \%$ of saturation. One $2.6-\mathrm{kW}$ blower provided air continuously to three BFT tanks through a diffuser grid on the bottom of each tank. Water only was added to replace losses to evaporation (ponds and tanks) and seepage (ponds), but the volume added was not quantified. Salt was added to all culture units to ensure that chloride concentration exceeded $100 \mathrm{mg} / \mathrm{L}$. Feed-grade sodium bicarbonate was added as needed to the BFT tanks to maintain $\mathrm{pH}$ and total alkalinity.

Ponds and BFT tanks were filled on 8-9 April 2013 with well water (total alkalinity $=226.4 \mathrm{mg} / \mathrm{L}$ as $\mathrm{CaCO}_{3}$ ). Once full, $2.3 \mathrm{~m}^{3}$ of water from a HKDSNARC pond containing an algal bloom was added to each BFT tank to speed development of the algal bloom. Over the next $26 \mathrm{~d}$ BFT tanks each were fertilized with a total of $0.5 \mathrm{~kg} 9-27-0(\mathrm{~N}-\mathrm{P}-\mathrm{K}), 0.4 \mathrm{~kg}$ 46-0-0, and $4.5 \mathrm{~kg}$ dried molasses and beet pulp (Sweet45; Westway Feed Products, New Orleans, LA), and ponds each were fertilized with a total of $0.9 \mathrm{~kg}$ 9-27-0 (N-P-K), $3.1 \mathrm{~kg} 46-0-0$, and $146.7 \mathrm{~kg}$ rice bran. 
Channel catfish (Ictalurus punctatus) fingerlings (2012 year class; $47 \mathrm{~g} /$ fish) were stocked into ponds at $1.5 \mathrm{fish} / \mathrm{m}^{2}$ (14,820 fish/ha) and into BFT tanks at $12.6 \mathrm{fish} / \mathrm{m}^{2}(126,000 \mathrm{fish} / \mathrm{ha})$ on 19 April 2013 . The fish population in each culture unit was sampled periodically using a seine net to monitor fish growth. On each sample date at least three samples per culture unit of $25 \mathrm{fish} / \mathrm{sample}$ were weighed and the fish returned to the culture unit. No mortalities were recorded during sampling. All culture units were harvested completely $210 \mathrm{~d}$ after stocking. At harvest, a minimum of 75 fish per culture unit were weighed individually and remaining fish were weighed in bulk. Fish number was calculated by dividing the bulk weight by the mean individual weight. Individually weighed fish were assigned to size classes ( $\mathrm{kg} /$ fish [size range]): submarketable $(<0.34 \mathrm{~kg} /$ fish $)$, out-of-size (0.34-0.45 kg/fish), 0.45 (0.45-0.57 kg/fish), 0.57 (0.57-0.68 kg/fish), 0.68 (0.68-0.79 kg/fish), 0.79 (0.79-0.91 kg/fish), $0.91(0.91-1.02 \mathrm{~kg} /$ fish $)$ and $1.02(\geq 1.02 \mathrm{~kg} / \mathrm{fish})$. Fish were fed a $32 \%$ protein commercially extruded feed daily to apparent satiation and quantities recorded. Feed conversion ratio was calculated for each pond as the total feed (dry-weight basis) fed divided by the net fish yield. Animal care and experimental protocols were approved by the HKDSNARC Institutional Animal Care and Use Committee and conformed to ARS Policies and Procedures 130.4 and 635.1 .

Water samples were collected weekly from each culture unit at about $0800 \mathrm{~h}:$ A $90-\mathrm{cm}$ column sample was collected from ponds, and a $0.5-\mathrm{L}$ grab sample was collected from BFT tanks. Sample $\mathrm{pH}$ was measured electrometrically. Water was filtered through $0.2-\mu \mathrm{m}$ pore size membrane filter and analyzed for nitrite-nitrogen $\left(\mathrm{NO}_{2}-\mathrm{N}\right.$, diazotization), nitrate-nitrogen $\left(\mathrm{NO}_{3}-\mathrm{N}\right.$, cadmium reduction), and soluble reactive phosphorus $\left(\mathrm{PO}_{4}-\mathrm{P}\right.$, ascorbic acid method) using flow injection analysis according to manufacturer instructions (FIAlab 2500; FIAlab Instruments, Bellevue, WA, USA). Flow injection analysis also was used to quantify total ammonia-nitrogen (TAN) fluorometrically in filtered samples using the o-phthaldialdehyde method (Genfa and Dasgupta 1989). Water samples were filtered through a $0.45-\mu \mathrm{m}$ pore size glass fiber filter for chlorophyll $a$ analysis. Chlorophyll $a$ was extracted in 2:1 chloroform:methanol from the phytoplankton (planktonic algae and cyanobacteria as well as those associated with the biofloc) retained on the filter, and the chlorophyll $a$ concentration in the extract was determined by spectroscopy (Lloyd and Tucker 1988).

Dissolved oxygen (DO) and temperature in each pond and tank were monitored continuously (10-s scan rate) by a galvanic oxygen sensor (Type III, Oxyguard, Birkerød, Denmark) and a thermister (Model 109, Campbell Scientific, Logan, UT, USA) connected to a data logger (Model CR206 or CR1000, Campbell Scientific, Logan, UT, USA). Mean $( \pm$ SD) DO was $6.4 \pm 1.7$ and $7.2 \pm 1.3 \mathrm{mg} / \mathrm{L}$ in ponds and BFT tanks, respectively. Mean 
$( \pm \mathrm{SD})$ water temperature was $25.0 \pm 5.0$ and $24.6 \pm 5.2^{\circ} \mathrm{C}$ in ponds and BFT tanks, respectively.

The one essential employee authorized to work during the 1-16 October 2013 U.S. government shutdown ensured fish well-being, fed fish, and maintained water levels as needed. All other activities were suspended.

After confirming homogeneity of variance and normality, data were analyzed using the two-tailed $t$-test (TTEST), linear regression (REG), and frequency (FREQ) procedures of SAS version 9.4. The repeated measures mixed-models procedure (MIXED) was used to compare slopes of growth curves. Percent data were arcsin transformed. Feed conversion ratio (FCR) data could not be normalized and were analyzed by nonparametric one-way analysis of variance (NPAR1WAY).

\section{Results and discussion}

Water-quality dynamics varied between treatments. Feed input and culture environment were the main factors that affected water quality. Compared to ponds, daily feed rate in BFT tanks was high beginning at stocking because stocking rate was 8.4 times greater. During the first $60 \mathrm{~d}$, fish in BFT tanks were fed a mean of $35.6 \mathrm{~g} / \mathrm{m}^{3}$ feed daily, significantly greater $(\mathrm{P}<0.001)$ than the $5.2 \mathrm{~g} / \mathrm{m}^{3}$ mean daily ration for fish in ponds. A total of $1,828 \mathrm{~g} / \mathrm{m}^{3}$ of feed was fed to fish in BFT tanks compared to $292 \mathrm{~g} / \mathrm{m}^{3}$ fed to fish in ponds during this time. High daily feed rates were sustained from days $86-162$ and averaged 100.4 and $18.0 \mathrm{~g} / \mathrm{m}^{3}$ for BFT tanks and ponds, respectively. And the $13.7 \mathrm{~kg} / \mathrm{m}^{3}$ of feed consumed by fish in the BFT system during the entire study was significantly higher $(\mathrm{P}<0.001)$ than the $2.2 \mathrm{~kg} / \mathrm{m}^{3}$ consumed by fish in earthen ponds. Mean daily feed ration and total feed consumed by fish in ponds and the BFT system were consistent with results from previous channel catfish studies in ponds and in the BFT system (Green 2010; Green and Rawles 2010, 2011; Green and Schrader 2015; Green et al. 2014; Schrader et al. 2011).

Chlorophyll a concentration (Figure 1), an indicator of phytoplankton biomass, was similar in ponds and the BFT system at the beginning of the study (averaging $264.0 \mathrm{mg} / \mathrm{m}^{3}$ ) and corresponded to a moderate phytoplankton bloom. During the first $60 \mathrm{~d}$ after fish were stocked, chlorophyll $a$ averaged $144 \mathrm{mg} / \mathrm{m}^{3}$ in ponds compared to $1,720 \mathrm{mg} / \mathrm{m}^{3}$ in the BFT system. Low nutrient input likely contributed to the initial decline in pond chlorophyll $a$ concentration. In the BFT system, high feed nutrient input beginning at stocking resulted in rapid phytoplankton growth, and mean chlorophyll $a$ concentration during the first 4-8 weeks was consistent with concentrations reported previously for channel catfish BFT culture (Green 2010; Green et al. 2014; Schrader et al. 2011). Subsequently, chlorophyll $a$ concentration in both treatments converged to a mean of $534 \mathrm{mg} / \mathrm{m}^{3}$ that 


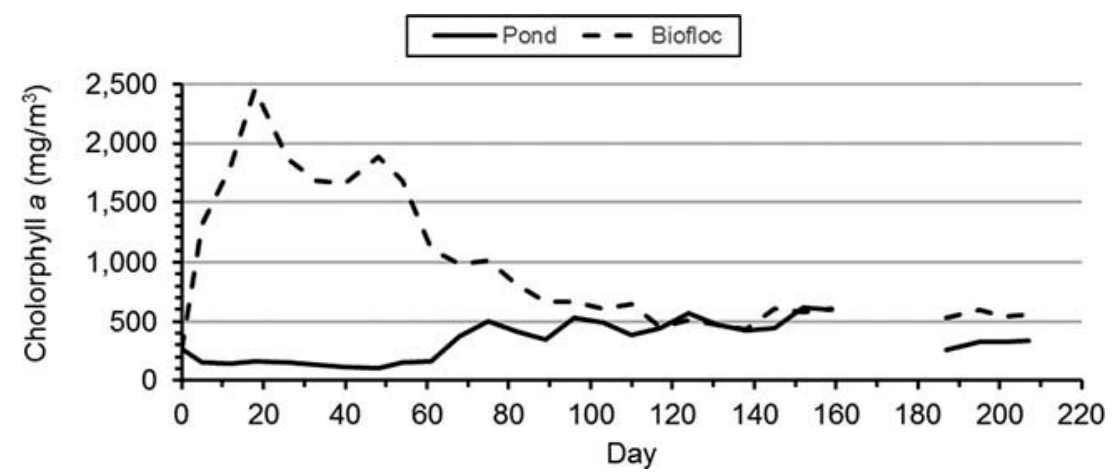

Figure 1. Mean chlorophyll $a$ concentration in earthen ponds or the biofloc technology production system stocked with channel catfish during the 210-day study. The gap in data corresponds to the 1-16 October 2013 shutdown of the U.S. government.

persisted throughout the remainder of the experiment. Chlorophyll $a$ concentration did not differ significantly between treatments on day 159 (immediately before the government shut down; $\mathrm{P}=0.878$ ) or on day 207 (just before harvest; $\mathrm{P}=0.175$ ).

Increased phytoplankton biomass can be important in sustaining dissolved oxygen concentration in aquaculture systems, particularly when the algal community is dominated by eukaryotes such as chlorophytes and diatoms, which are better oxygenators of the water compared to bloom-forming cyanobacteria. Blooms of planktonic, filamentous cyanobacteria (e.g., Raphidiopsis spp., Planktothrix [Oscillatoria] agardhii, P. perornata) commonly dominate phytoplankton communities during late summer in catfish production ponds (Van der Ploeg and Tucker 1993), whereas the consistently high nutrient loading rates and constant mixing of water in the BFT system contributes to phytoplankton communities dominated by chlorophytes and diatoms (Schrader et al. 2011). Some cyanobacteria species produce toxins and off-flavor compounds, and bloom-forming cyanobacteria are a poor base for aquatic food chains and can deplete dissolved oxygen in ponds following the sudden die-off of the bloom (Paerl and Tucker 1995).

Chlorophyll $a$ concentration increased in ponds $\left(\mathrm{R}^{2}=0.651, \mathrm{P}<0.001\right)$ but decreased in the BFT system $\left(\mathrm{R}^{2}=0.671, \mathrm{P}<0.001\right)$ as the weekly mean of daily feed input increased during the 210-d study. Increasing chlorophyll $a$ concentration in response to increasing feed nutrient input is common in earthen ponds used for the intensive culture of channel catfish (Boyd and Tucker 1998; Torrans 2005). However, the negative chlorophyll $a$-feed input relationship in the BFT system is in contrast to other published studies on channel catfish BFT culture where chlorophyll $a$ concentration was independent of feed input (Green et al. 2014) or increased with increased feed input (Green 2010; Schrader et al. 2011). Variation among studies in fish stocking rate and initial size and the rapid increase to sustained high chlorophyll $a$ 
concentrations likely contributed to the different observed chlorophyll $a$-feed input relationships.

Dissolved inorganic nitrogen (DIN) dynamics differed between ponds and the BFT system (Figure 2). Concentrations of TAN and $\mathrm{NO}_{2}-\mathrm{N}$ in ponds were higher and more variable, and $\mathrm{NO}_{3}-\mathrm{N}$ was lower. Excretion of feed nitrogen by fish in ponds exceeded phytoplankton TAN uptake and resulted in a TAN spike of $3.2 \mathrm{mg} / \mathrm{L}$ on day 54 followed by a secondary TAN spike of $1.0 \mathrm{mg} / \mathrm{L}$ on day 96. Phytoplankton productivity in ponds likely was nitrogen-limited prior to the first TAN spike because chlorophyll $a$ concentration increased rapidly from a mean of $149.8 \mathrm{mg} / \mathrm{m}^{3}$ on day 54 to $503.8 \mathrm{mg} / \mathrm{m}^{3}$ on day 75. Phytoplankton TAN uptake in ponds during the remainder of the study kept TAN concentration low. Algal uptake of TAN is the primary mechanism that controls TAN concentration in catfish ponds (Hargreaves 1998, 2006; Hargreaves and Tucker 1996). A $\mathrm{NO}_{2}-\mathrm{N}$ spike (days 110-138) that followed the TAN spike (day 96) may indicate that some nitrification occurred in ponds. Nitrate concentration would be expected to increase following nitrification, but data are not available because it was not possible to conduct water-quality analyses during the government shutdown. Mean $\mathrm{NO}_{3}-\mathrm{N}$ concentration increased from $0.5 \mathrm{mg} / \mathrm{L}$ immediately preceding the shutdown to $2.6 \mathrm{mg} / \mathrm{L}$ afterwards, which supports the occurrence of nitrification. The observed DIN dynamics in ponds in the present study, including the minor role of nitrification, were consistent with those observed in commercial catfish ponds (Tucker and Van der Ploeg 1993). In the BFT system, DIN dynamics were driven initially by phytoplankton TAN uptake followed by onset of nitrification beginning about day 30: An initial TAN spike was followed by a $\mathrm{NO}_{2}-\mathrm{N}$ spike followed subsequently by increasing $\mathrm{NO}_{3}-\mathrm{N}$ concentration. Nitrification typically begins 4-6 weeks into the culture period (Green 2010; Green et al. 2014; Ray et al. 2011) because

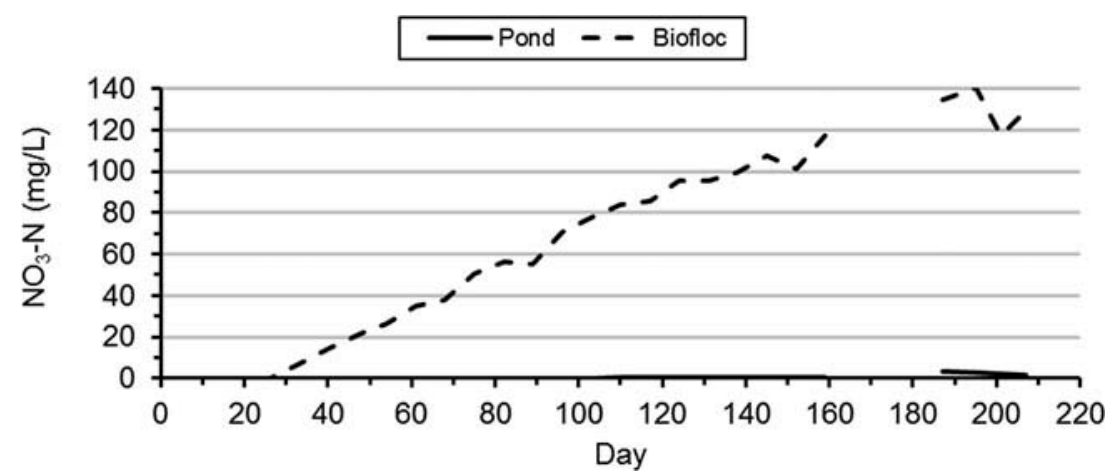

Figure 2. Mean total ammonia-nitrogen ( $\mathrm{NH}_{4}-\mathrm{N}$, top), nitrite-nitrogen $\left(\mathrm{NO}_{2}-\mathrm{N}\right.$, middle), and nitrate-nitrogen $\left(\mathrm{NO}_{3}-\mathrm{N}\right.$, bottom) concentrations in earthen ponds or the biofloc technology production system stocked with channel catfish during the 210-day study. The gap in data corresponds to the 1-16 October 2013 shutdown of the U.S. government. 
nitrifying bacteria grow slowly (Hargreaves 2006). Algal uptake and nitrification acted to maintain TAN and $\mathrm{NO}_{2}-\mathrm{N}$ concentrations at low levels in the BFT system despite the high feed rates. No significant differences $(\mathrm{P}>0.050)$ between treatments on days 159 or 207 were detected for TAN or $\mathrm{NO}_{2}-\mathrm{N}$ concentration, but $\mathrm{NO}_{3}-\mathrm{N}$ concentration was significantly higher $(\mathrm{P}<0.001)$ in the BFT system on both days.

Pond $\mathrm{pH}$ oscillated around $\mathrm{pH} 8.1$ throughout the study, whereas in the BFT system $\mathrm{pH}$ declined beginning about day 40 because of nitrification but was maintained around $\mathrm{pH} 7.4$ by periodic addition of sodium bicarbonate (Figure 3$)$. Pond $\mathrm{pH}$ was significantly lower $(\mathrm{P}<0.001)$ than $\mathrm{BFT}$ system $\mathrm{pH}$ on day 159, but not different $(P=0.060)$ on day 207.

Chronic or acute exposure to elevated unionized ammonia concentration can decrease fish growth or be toxic (Hargreaves and Kucuk 2001). The proportion of unionized ammonia can be calculated based on water temperature and $\mathrm{pH}$ (Emerson et al. 1975) and will vary diurnally in ponds in response to photosynthesis. Pond $\mathrm{pH}$ is lowest in the morning because of nocturnal pond community respiration and increases throughout the day until maximum photosynthesis, after which it declines until photosynthesis resumes the next day. Elevated TAN concentrations occurred during the present study on days 40-61 (TAN $=2-4 \mathrm{mg} / \mathrm{L}$ ) and on days $82-110$ $(\mathrm{TAN}=0.5-1.3 \mathrm{mg} / \mathrm{L})$. Based on mean water temperature (27.9 and $29.7^{\circ} \mathrm{C}$, respectively) and mean early morning $\mathrm{pH}$ (8.1 and 8.2 , respectively) during each event, mean unionized ammonia concentration was $0.19 \mathrm{mg} / \mathrm{L}$ (range $0.01-0.34 \mathrm{mg} / \mathrm{L}$ ) and $0.07 \mathrm{mg} / \mathrm{L}$ (range $0.01-0.14 \mathrm{mg} / \mathrm{L}$ ) during the first and second events respectively. These concentrations are less than the $\mathrm{LC}_{50}$ and growth-limiting unionized ammonia concentrations reported for channel catfish (Hargreaves and Kucuk 2001).

Soluble reactive phosphorus $\left(\mathrm{PO}_{4}-\mathrm{P}\right)$ concentration (Figure 4) was similar in ponds and the BFT system at the start of the experiment. Pond $\mathrm{PO}_{4}-\mathrm{P}$

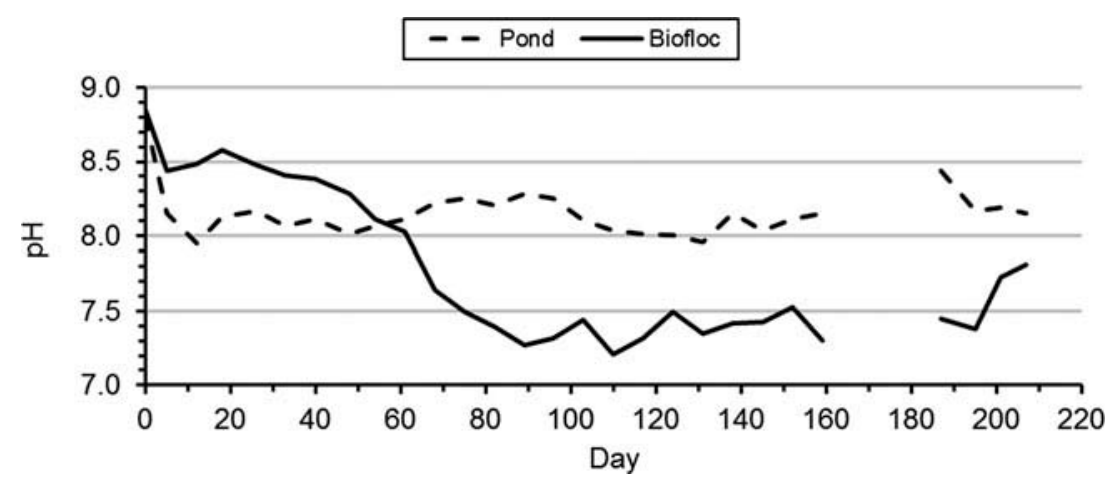

Figure 3. Mean $\mathrm{pH}$ in earthen ponds or the biofloc technology production system stocked with channel catfish during the 210-day study. The gap in data corresponds to the 1-16 October 2013 shutdown of the U.S. government. 


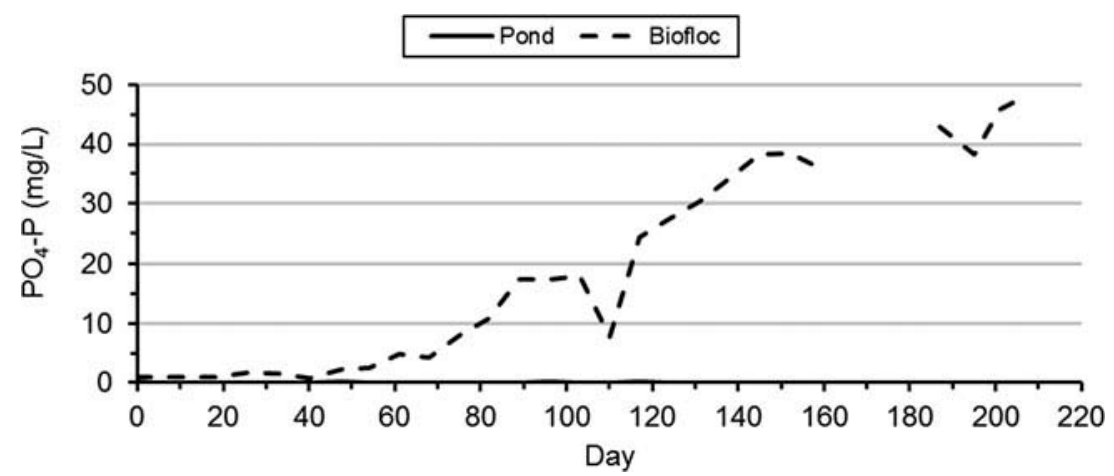

Figure 4. Mean soluble reactive phosphorus $\left(\mathrm{PO}_{4}-\mathrm{P}\right)$ concentrations in earthen ponds or the biofloc technology production system stocked with channel catfish during the 210-day study. Pond $\mathrm{PO}_{4}-\mathrm{P}$ concentration remained low throughout the study, averaging $0.04 \mathrm{mg} / \mathrm{L}$. The gap in data corresponds to the 1-16 October 2013 shutdown of the U.S. government.

concentrations remained low throughout the culture cycle, averaging $0.04 \mathrm{mg} / \mathrm{L}$. Similar $\mathrm{PO}_{4}-\mathrm{P}$ concentrations were observed in other catfish pond production trials at HKDSNARC and elsewhere (Green and Rawles 2010, 2011; Tucker et al. 1996). In contrast, $\mathrm{PO}_{4}-\mathrm{P}$ concentration increased linearly $\left(\mathrm{R}^{2}=0.915, \mathrm{P}<0.001\right)$ with time beginning on day 40 in the BFT system and was a consequence of the high feed input. Mean $\mathrm{PO}_{4}-\mathrm{P}$ concentration in the BFT system was significantly higher $(\mathrm{P}<0.001)$ than in ponds on days 159 and 207.

In addition to feed input, two other factors contributed to the differences in water quality observed between the two systems: The BFT system did not contain soil and did not lose water to seepage because of the HDPE liner. Major interactions occur between sediment and the overlying water column in catfish ponds. Sediment oxygen demand is a major component of wholepond respiration and in a $1.5-\mathrm{m}$-deep pond is estimated to comprise $20 \%$ of whole-pond respiration (Steeby et al. 2004). However, water column respiration in a BFT system, measured either by dark-bottle respiration or 5-d biochemical oxygen demand, is about 30 times greater than in catfish ponds (Boyd and Gross 1999; Vinatea et al. 2010; Ray and Lotz 2014; B. W. Green, unpublished data). In ponds, nutrient transformations that occur in pond sediment include nitrification and denitrification (Gross et al. 2000; Hargreaves 1998), accumulation of organic nitrogen (Gross et al. 2000), and $\mathrm{PO}_{4}-\mathrm{P}$ adsorption and solubilization in sediment pore water (Masuda and Boyd 1994a, 1994b) and can be affected by the status of sediment oxygenation (Hargreaves and Tucker 1996). Nitrification clearly occurred in the BFT system, and $\mathrm{PO}_{4}-\mathrm{P}$ accumulated because sediment was absent, and while not measured, denitrification may have occurred in anaerobic microenvironments, possibly within the core of larger $(>100 \mu \mathrm{m}$ diameter) floc particles. Seepage represents the major source of water loss from earthen catfish ponds 
(Boyd 1982, 1985; Tucker 1996). Seepage rate is affected by soil type and construction practices and varies from 10 to $25 \mathrm{~mm} / \mathrm{d}$ in well-constructed ponds on high shrink-swell soils (Boyd 1982; Tucker 1996).

Fish in both treatments grew rapidly throughout the study (Figure 5). Fish were sampled periodically for growth, and growth curve analysis showed that intercepts and slopes did not differ significantly $(\mathrm{P}=0.243)$ between treatments. However, at harvest, fish from ponds were significantly larger than those from the BFT system $(\mathrm{P}=0.035$; Table 1$)$. Stocking rate is known to affect channel catfish growth over a variety of production environments (e.g., Baumgarner et al. 2005; Dunham et al. 1990; Li et al. 2003). Given that the stocking rate in the BFT system was 8.4 times higher than in ponds, social interactions among individual fish, specifically competition for food, could result in higher size variation (as measured by the coefficient of variation, $\mathrm{CV}$ ) as was reported for other fish in response to increased stocking rate (Brett 1979; Huss et al. 2008; Jobling 1983). Individual weight CV at stockout was $26.4 \%$ and at harvest CVs ranged from $25.2 \%-28.8 \%$ for fish in ponds and $22.3 \%-27.4 \%$ for fish in the BFT system and would not be expected to differ. Since fish were fed daily to apparent satiation, competition for food should be negligible. In fact, mean feed consumption per fish was

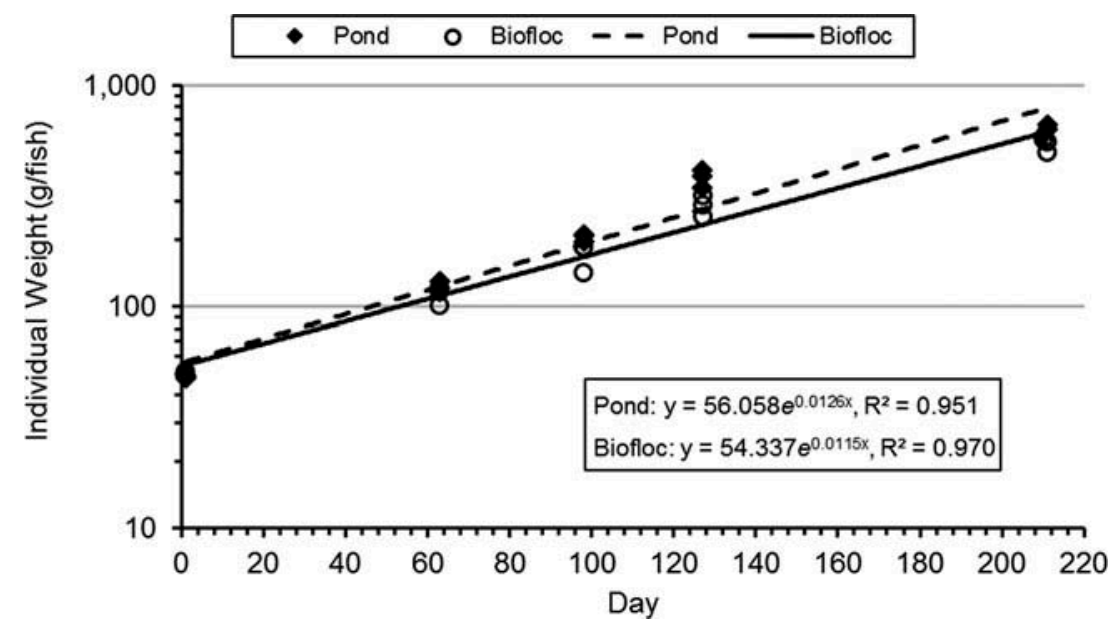

Figure 5. Growth of channel catfish in earthen ponds and the biofloc system during the 210 study.

Table 1. Mean $( \pm \mathrm{SE})$ gross and net fish yields, individual weight, survival, and feed conversion ratio $(F C R)$ for channel catfish harvested from earthen ponds or the biofloc system after a 210day experiment.

\begin{tabular}{lccccc}
\hline Treatment & Gross Yield $\left(\mathrm{kg} / \mathrm{m}^{3}\right)$ & Net Yield & Individual Weight $(\mathrm{g} /$ fish) & Survival (\%) & FCR \\
\hline Pond & $1.5 \pm 0.0$ & $1.4 \pm 0.0$ & $630 \pm 18$ & $92.2 \pm 0.4$ & $1.6 \pm 0.0$ \\
Biofloc & $7.7 \pm 0.5$ & $6.9 \pm 0.5$ & $542 \pm 22$ & $96.7 \pm 1.0$ & $2.0 \pm 0.1$ \\
Pr $>t$ & $<0.001$ & $<0.001$ & 0.035 & 0.442 & 0.038 \\
\hline
\end{tabular}


921 and $966 \mathrm{~g} /$ fish for the pond and BFT treatments respectively and did not differ significantly $(P=0.275)$. Differential mortality does not explain the treatment difference for mean final individual weight because mean survivals were high and not significantly different. Concentrations of water-quality variables in the present experiment would not be expected to affect individual fish feed consumption or growth. Density-induced stress, as indicated by serum cortisol concentration, is thought to negatively affect fish growth, but results are equivocal (Ainsworth et al. 1985; Gatlin et al. 1986; Klinger et al. 1983). Although feed consumption on an individual fish basis did not differ significantly between treatments, FCR did. This may indicate that density-induced stress negatively affected digestive physiology of fish in the BFT system. It is possible that fish in the BFT system were overfed, which also would result in an elevated FCR. However, no excess feed was noted on the water surface of the BFT system tanks several hours after feeding.

Significant $(\mathrm{P}<0.001)$ treatment differences were detected for size classes of harvested fish (Figure 6). Results of frequency analysis showed that the number of submarketable fish approximated the expected number for each treatment. There were fewer than expected out-of-size and $0.45 \mathrm{~kg} /$ fish sizeclass fish harvested from ponds, whereas for the BFT system there were greater than expected numbers. Numbers of fish in the $0.57,0.68$, and $1.02 \mathrm{~kg} /$ fish size classes in each treatment approximated expected numbers. And there were greater than expected 0.79 and $0.91 \mathrm{~kg} / \mathrm{fish}$ size-class fish

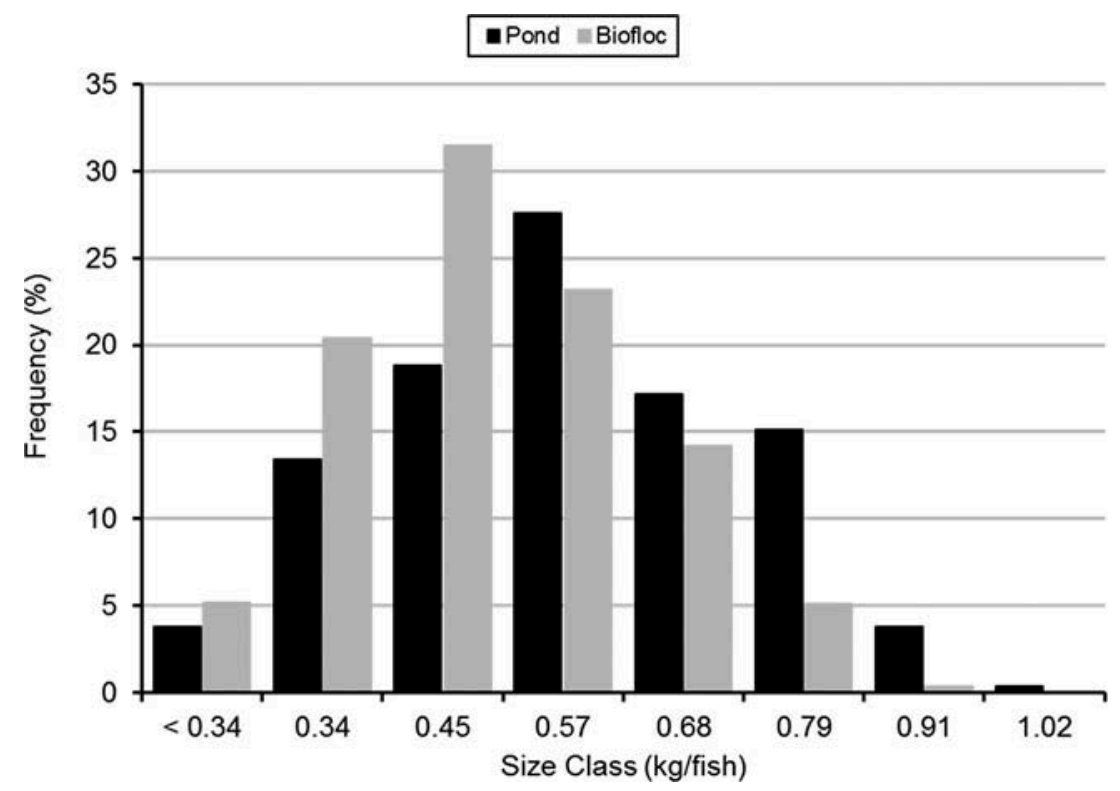

Figure 6. Size distribution of channel catfish harvested after 210 days from earthen ponds or the biofloc technology production system. Fish in the $<0.34$ and $0.34 \mathrm{~kg} /$ fish size classes are considered submarketable and out-of-size, respectively. 
harvested from ponds, whereas for the BFT system there were fewer than expected numbers. Density-related social interactions appear to have affected fish growth more in the BFT system.

Gross fish yield (GFY) and net fish yield (NFY) were significantly greater $(\mathrm{P}<0.001)$ in the BFT system as would be expected from the higher stocking rate (Table 1). Channel catfish yields in the current experiment were similar to yields obtained in previous experiments in ponds (Green and Rawles 2010, 2011; Li et al. 2004) and the BFT system (Green and Schrader 2015; Green et al. 2014; Schrader et al. 2011). Fish survival was high in ponds and the BFT system and did not differ significantly between treatments. Feed conversion ratio, as noted previously, was significantly higher in the BFT system; mean FCR for pond- and BFT system-reared fish were consistent with reported values (Green and Rawles 2010, 2011; Green and Schrader 2015; Green et al. 2014; Li et al. 2004).

There were significant differences between treatments among size classes of harvested fish (Table 2). Catfish sizes accepted by processing plants range from $0.45-0.57$ to $1.81-2.26 \mathrm{~kg} /$ fish, but the preferred size range varies from plant to plant and over time in response to market demands (Wiese et al. 2006). Processors likely prefer a tighter size range $(0.68-1.13 \mathrm{~kg} / \mathrm{fish})$ with minimal numbers of fish $1.36 \mathrm{~kg}$ and larger. Catfish that are too small to eat (generally $<0.35 \mathrm{~kg} /$ fish) are rejected by the plant, whereas fish that are large enough to eat but outside prevailing specifications are considered out-of-size $(0.35-0.45$ and $>2.26 \mathrm{~kg} /$ fish) and are discounted (Wiese et al. 2006). In the present experiment, submarketable fish did not differ significantly $(P=0.241)$ between treatments and ranged from $3 \%-6 \%$ of the population. There were $50 \%$ more out-of-size in the BFT system than in ponds, but the difference was not significant $(P=0.071)$. Significantly greater percentages of fish harvested from ponds were in the larger size classes. No fish in either treatment exceeded $1.13 \mathrm{~kg}$. Fish in both treatments would need to be graded by size before being sent for processing to minimize the number of fish rejected or discounted (Trimpey et al. 2004). Despite differences in the size-class composition of harvested fish, gross fish yield was higher in the BFT system because of the higher initial stocking density.

Table 2. Mean $( \pm$ SE) percentage of channel catfish population harvested after a 210-day experiment from earthen ponds or the biofloc technology production system that was $<0.35$ (submarketable), $0.35-0.45$ (out-of-size), $\geq 0.45, \geq 0.57$, or $\geq 0.68 \mathrm{~kg} / \mathrm{fish}$.

\begin{tabular}{lccccc}
\hline & $<0.35$ & $0.35-0.45$ & $\geq 0.45$ & $\geq 0.57$ & $\geq 0.68$ \\
\cline { 2 - 6 } Treatment & \multicolumn{5}{c}{$(\%)$} \\
\hline Pond & $2.9 \pm 0.0$ & $14.1 \pm 0.0$ & $83.0 \pm 0.0$ & $64.0 \pm 0.0$ & $39.4 \pm 0.3$ \\
Biofloc & $6.0 \pm 0.3$ & $21.6 \pm 0.1$ & $72.1 \pm 0.4$ & $39.3 \pm 0.4$ & $18.0 \pm 0.2$ \\
Pr $>t$ & 0.241 & 0.071 & 0.102 & 0.017 & 0.026 \\
\hline
\end{tabular}


In summary, pond culture of channel catfish is much less intensive than the BFT system. Phytoplankton uptake is the main TAN sink in ponds, whereas phytoplankton uptake and ammonia oxidation by nitrifying bacteria are the main TAN sinks in the outdoor BFT system.

Total GFY and NFY from earthen ponds are less than from the BFT system because of lower stocking and feeding rates. Although a significantly higher percentage of fish harvested from earthen ponds were of market size, the GFY and NFY of market-size fish from the BFT system was significantly higher because of the higher stocking rate. Density-related social interactions that appear to limit fish growth in the BFT system need to be studied and resolved.

\section{Acknowledgments}

We thank Greg O'Neal, Paxton Harper, and William Schiederer for their assistance during this study. Mention of trade names or commercial products is solely for the purpose of providing specific information and does not imply recommendation or endorsement by the U.S. Department of Agriculture (USDA). USDA is an equal opportunity provider and employer.

\section{References}

Ainsworth, A. J., P. R. Bowser, and M. H. Beleau. 1985. Serum cortisol levels in channel catfish from production ponds. The Progressive Fish-Culturist 47:176-181. doi:10.1577/ 1548-8640(1985)47<176:SCLICC >2.0.CO;2.

Baumgarner, B. L., T. E. Schwedler, A. G. Eversole, D. E. Brune, and J. A. Collier. 2005. Production characteristics of channel catfish, Ictalurus punctatus, stocked at two densities in the Partitioned Aquaculture System. Journal of Applied Aquaculture 17:75-83. doi:10.1300/J028v17n02_06.

Boyd, C. E. 1982. Hydrology of small experimental fish ponds at Auburn, Alabama. Transactions of the American Fisheries Society 111:638-644. doi:10.1577/1548-8659(1982) $111<638$ :HOSEFP $>2.0$. CO; 2 .

Boyd, C. E. 1985. Chemical budgets for channel catfish ponds. Transactions of the American Fisheries Society 114:291-298. doi:10.1577/1548-8659(1985)114<291:CBFCCP >2.0.CO;2.

Boyd, C. E., and A. Gross. 1999. Biochemical oxygen demand in channel catfish Ictalurus punctatus pond waters. Journal of the World Aquaculture Society 30:349-356. doi:10.1111/ jwas.1999.30.issue-3.

Boyd, C. E., and C. S. Tucker. 1998. Pond aquaculture water quality management. Boston: Kluwer.

Brett, J. R. 1979. Environmental factors and growth. In Fish physiology, Volume VIII, ed. W. S. Hoar, D. J. Randall, and J. R. Brett, 599-567. New York/London: Academic Press.

Brown, T. W., C. S. Tucker, and B. L. Rutland. 2016. Performance evaluation of four different methods for circulating water in commercial-scale, split-pond aquaculture systems. Aquacultural Engineering 70:33-41. doi:10.1016/j.aquaeng.2015.12.002.

Brune, D. E., G. Schwartz, A. G. Eversole, J. A. Collier, and T. E. Schwedler. 2004. Partitioned aquaculture systems. In Biology and culture of channel catfish, ed. C. S. Tucker and J. A. Hargreaves, 561-584. Amsterdam: Elsevier. 
Dunham, R. A., R. E. Brummett, M. O. Ella, and R. O. Smitherman. 1990. Genotypeenvironment interactions for growth of blue, channel and hybrid catfish in ponds and cages at varying densities. Aquaculture 85:143-151. doi:10.1016/0044-8486(90)90013-D.

Emerson, K., R. C. Russo, R. E. Lund, and R. V. Thurston. 1975. Aqueous ammonia equilibrium calculations: Effect of $\mathrm{pH}$ and temperature. Journal of the Fisheries Research Board of Canada 32:2379-2383. doi:10.1139/f75-274.

Gatlin, D. M., W. E. Poe, R. P. Wilson, A. J. Ainsworth, and P. R. Bowser. 1986. Effects of stocking density and vitamin $\mathrm{C}$ status on vitamin E-adequate and vitamin E-deficient fingerling channel catfish. Aquaculture 56:187-195. doi:10.1016/0044-8486(86)90334-0.

Genfa, Z., and P. K. Dasgupta. 1989. Fluorometric measurement of aqueous ammonium ion in a flow injection system. Analytical Chemistry 61:408-412. doi:10.1021/ac00180a006.

Green, B. W. 2010. Effect of channel catfish stocking rate on yield and water quality in an intensive, mixed suspended-growth production system. North American Journal of Aquaculture 72:97-106. doi:10.1577/A09-020.1.

Green, B. W., and S. D. Rawles. 2010. Comparative growth and yield of channel catfish and channel $\times$ blue hybrid catfish fed a full or restricted ration. Aquaculture Research 41:e109e119. doi:10.1111/are.2010.41.issue-9.

Green, B. W., and S. D. Rawles. 2011. Comparative production of channel catfish and channel $\times$ blue hybrid catfish subjected to two minimum dissolved oxygen concentrations. North American Journal of Aquaculture 73:311-319. doi:10.1080/15222055.2011.602266.

Green, B. W., and K. K. Schrader. 2015. Effect of stocking large channel catfish in a biofloc technology production system on production and incidence of common microbial off-flavor compounds. Journal of Aquaculture Research and Development 6:314320.

Green, B. W., K. K. Schrader, and P. W. Perschbacher. 2014. Effect of stocking biomass on solids, phytoplankton communities, common off-flavors, and production parameters in a channel catfish biofloc technology production system. Aquaculture Research 45:1442-1458. doi:10.1111/are.12096.

Gross, A., C. E. Boyd, and C. W. Wood. 2000. Nitrogen transformations and balance in channel catfish ponds. Aquacultural Engineering 24:1-14. doi:10.1016/S0144-8609(00) 00062-5.

Hargreaves, J. A. 1998. Nitrogen biogeochemistry of aquaculture ponds. Aquacultural Engineering 166:181-212.

Hargreaves, J. A. 2006. Photosynthetic suspended-growth systems in aquaculture. Aquacultural Engineering 34:344-363. doi:10.1016/j.aquaeng.2005.08.009.

Hargreaves, J. A., and S. Kucuk. 2001. Effects of diel un-ionized ammonia fluctuation on juvenile hybrid striped bass, channel catfish, and blue tilapia. Aquaculture 195:163-181. doi:10.1016/S0044-8486(00)00543-3.

Hargreaves, J. A., and C. S. Tucker. 1996. Evidence for control of water quality in channel catfish Ictalurus punctatus ponds by phytoplankton biomass and sediment oxygenation. Journal of the World Aquaculture Society 27:21-29. doi:10.1111/jwas.1996.27.issue-1.

Huss, M., P. Byström, and L. Persson. 2008. Resource heterogeneity, diet shifts and intracohort competition: Effects on size divergence in YOY fish. Oecologia 158:249-257. doi:10.1007/s00442-008-1140-9.

Jobling, M. 1983. Effect of feeding frequency on food intake and growth of Arctic charr, Salvelinus alpinus L. Journal of Fish Biology 23:177-185. doi:10.1111/jfb.1983.23.issue-2.

Johnson, K., C. Engle, and B. Wagner. 2014. Comparative economics of U.S. catfish production strategies: Evidence from a cross-sectional survey. Journal of the World Aquaculture Society 45:279-289. doi:10.1111/jwas.2014.45.issue-3. 
Klinger, H., H. Delventhal, and V. Hilge. 1983. Water quality and stocking density as stressors of channel catfish (Ictalurus punctatus Raf.). Aquaculture 30:263-272. doi:10.1016/00448486(83)90168-0.

Li, M. H., B. B. Manning, E. H. Robinson, and B. G. Bosworth. 2003. Effect of dietary protein concentration and stocking density on production characteristics of pond-raised channel catfish Ictalurus punctatus. Journal of the World Aquaculture Society 34:147-155. doi:10.1111/j.1749-7345.2003.tb00051.x.

Li, M. H., B. B. Manning, E. H. Robinson, and B. G. Bosworth. 2004. Effects of dietary protein concentration on production characteristics of pond-raised channel catfish fed once daily or once every other day to satiation. North American Journal of Aquaculture 66:184-190. doi:10.1577/A03-052.1.

Lloyd, S. W., and C. S. Tucker. 1988. Comparison of three solvent systems for extraction of chlorophyll a from fish pond phytoplankton communities. Journal of the World Aquaculture Society 19:36-40. doi:10.1111/jwas.1988.19.issue-2.

Masuda, K., and C. E. Boyd. 1994a. Phosphorus fractions in soil and water of aquaculture ponds built on clayey Ultisols at Auburn, Alabama. Journal of the World Aquaculture Society 25:379-395. doi:10.1111/jwas.1994.25.issue-3.

Masuda, K., and C. E. Boyd. 1994b. Chemistry of sediment pore water in aquaculture ponds built on clayey Ultisols at Auburn, Alabama. Journal of the World Aquaculture Society 25:396-404. doi:10.1111/jwas.1994.25.issue-3.

Paerl, H. W., and C. S. Tucker. 1995. Ecology of blue-green algae in aquaculture ponds. Journal of the World Aquaculture Society 26:109-131. doi:10.1111/jwas.1995.26.issue-2.

Park, J., D. Heikes, M. Recsetar, and L. A. Roy. 2014. Performance evaluation and engineering considerations for a modular- and culvert-based paddlewheel circulator for split-pond systems. Aquacultural Engineering 61:1-8. doi:10.1016/j.aquaeng.2014.05.002.

Ray, A. J., K. S. Dillon, and J. M. Lotz. 2011. Water quality dynamics and shrimp (Litopenaeus vannamei) production in intensive, mesohaline culture systems with two levels of biofloc management. Aquacultural Engineering 45:127-136. doi:10.1016/j.aquaeng.2011.09.001.

Ray, A. J., and J. M. Lotz. 2014. Comparing a chemoautotrophic-based biofloc system and three heterotrophic-based systems receiving different carbohydrate sources. Aquacultural Engineering 63:54-61. doi:10.1016/j.aquaeng.2014.10.001.

Schrader, K. K., B. W. Green, and P. W. Perschbacher. 2011. Development of phytoplankton communities and common off-flavors in a biofloc technology system used for the culture of channel catfish (Ictalurus punctatus). Aquacultural Engineering 45:118-126. doi:10.1016/ j.aquaeng.2011.08.004.

Steeby, J. A., J. A. Hargreaves, C. S. Tucker, and T. P. Cathcart. 2004. Modeling industry-wide sediment oxygen demand and estimation of the contribution of sediment to total respiration in commercial channel catfish ponds. Aquacultural Engineering 31:247-262. doi:10.1016/j.aquaeng.2004.05.006.

Torrans, E. L. 2005. Effect of oxygen management on culture performance of channel catfish in earthen ponds. North American Journal of Aquaculture 67:275-288. doi:10.1577/A04071.1 .

Trimpey, J., C. Engle, D. Heikes, K. B. Davis, and A. Goodwin. 2004. A comparison of new in-pond grading technology to live-car grading for food-sized channel catfish (Ictalurus punctatus). Aquacultural Engineering 31:263-276. doi:10.1016/j.aquaeng.2004.05.003.

Tucker, C. S. 1996. The ecology of channel catfish culture ponds in northwest Mississippi. Reviews in Fisheries Science 4:1-55. doi:10.1080/10641269609388577.

Tucker, C. S., S. K. Kingsbury, J. W. Pote, and C. L. Wax. 1996. Effects of water management practices on discharge of nutrients and organic matter from channel catfish (Ictalurus punctatus) ponds. Aquaculture 147:57-69. doi:10.1016/S0044-8486(96)01342-7. 
Tucker, C. S., and M. van der Ploeg. 1993. Seasonal changes in water quality in commercial channel catfish ponds in Mississippi. Journal of the World Aquaculture Society 24:473-481. doi:10.1111/jwas.1993.24.issue-4.

Van der Ploeg, M., and C. S. Tucker. 1993. Seasonal trends in flavor quality of channel catfish, Ictalurus punctatus, from commercial ponds in Mississippi. Journal of Applied Aquaculture 3:121-140. doi:10.1300/J028v03n01_10.

Vinatea, L., A. O. Galvez, C. L. Browdy, A. Stokes, J. Venero, J. Haveman, B. L. Lewis, A. Lawson, A. Shuler, and J. W. Leffler. 2010. Photosynthesis, water respiration and growth performance of Litopenaeus vannamei in a super-intensive raceway culture with zero water exchange: Interaction of water quality variables. Aquacultural Engineering 42:17-24. doi:10.1016/j.aquaeng.2009.09.001.

Wiese, N., C. Engle, J. Trimpey, K. Quagrainie, and B. Green. 2006. Reducing catfish farm losses due to dockages assessed by processing plants. Journal of the World Aquaculture Society 37:60-73. doi:10.1111/jwas.2006.37.issue-1. 